\title{
Deregulation And Liberalization In The European Electricity Sector
}

Pere Palacín Farré, Ramón Llull University, IQS, Barcelona, Spain

Carlos Moslares García, Ramón Llull University, IQS, Barcelona, Spain

Hugo M. Hervitz, Nova Southeastern University, USA

\begin{abstract}
Since the 1990's, we have witnessed a global process of deregulation, liberalization and privatization in key economic sectors. This paper focuses on the way this process has evolved in a key sector - electricity - in a very important region - Europe. The paper shows that the European track record is quite mixed; i.e., increased competition in some countries and no discernible improvement in efficiency in others. Given that in some cases the whole reliability of the electricity supply system has been challenged, serious questions should be asked about the desirability of the whole process.
\end{abstract}

Keywords: Liberalization, Electrical Sector, Privatization

\section{INTRODUCTION}

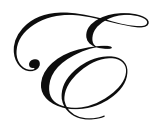

lectricity is an integral part of modern life and a reliable supply is an essential component of a country's quality of life. A high quality and reliable electricity network is also crucial for the proper functioning of all sectors of a country's economy. In order to guarantee high standards of quality and reliability in such a strategically important industry, European countries have historically chosen to rely on a single state-owned vertically integrated company that carried out all four key activities in the power delivery chain; i.e., generation, transmission, distribution and retailing.

These key activities require a great deal of coordination and require the smooth functioning of an integrated network. Thus, it has been traditionally assumed that the sector needed to be operated as a natural monopoly. This fact, combined with the strategic nature of the electricity sector, explains the high degree of state intervention that has prevailed for decades.

The integrated state-run system enabled the achievement of economies of scale and scope and allowed for the toleration of unprofitable activities which were compensated by more profitable ones. However, this state of affairs also allowed for serious errors to be committed due to the influence of powerful economic, political and corporate interest groups. Up until the 1970's, this model had broad support and was not questioned.

\section{THE ROAD TO LIBERALIZATION}

The first questioning of the efficiency of a natural monopoly in the electricity sector in the U.S. appeared in the early 1960's. Averch and Johnson (1962) showed that a private regulated monopoly has an incentive to overinvest in assets thus increasing the cost of electricity.

In the 1970's, the twin oil crises triggered a worldwide recession which turned out to be hard to overcome by means of traditional macroeconomic policies. It was in this environment that a new ideology began to flourish, especially in Britain and the U.S., favoring market-oriented private sector solutions. Thus, in the 1980's, President Ronald Reagan in the U.S. and Prime Minister Margaret Thatcher in Britain led a reassessment of conventional economic wisdom, based on deregulation, privatizations and market-oriented reforms. Liberalization in the electricity sector meant curtailing the role of the state, introducing competition wherever feasible in the supply chain, freedom of choice for consumers, and adoption of market-driven prices. 
The main factors that contributed to the liberalization process were:

- $\quad$ The sharp increase in oil prices, which resulted in a severe stagflation

- $\quad$ The increase in the size and importance of energy markets, triggered by the globalization of energy products and the development of interconnectivity between electricity and natural gas networks

- $\quad$ The weakening of the arguments in support of natural monopolies as the only way to exploit economies of scale

- $\quad$ The generalized trend favoring free markets and deregulation

- Privatizations were viewed as a convenient way to attract new needed investments which the Statesupported monopolies were not able or willing to undertake

- $\quad$ Dissatisfaction with the existing electricity monopolies who lacked incentives to improve service, reduce costs or modernize its infrastructure, and, moreover, were subject to political influences and lack of transparency which hurt economic efficiency

By the early 1990's, pressure was mounting for significant changes in the electricity sector.

\section{CHARACTERISTICS OF THE TRANSITION TO A COMPETITIVE MODEL}

The process of transition to a privatized and/or deregulated electricity sector requires significant legislative and structural changes. The International Energy Agency recommended that the process should ensure proper attention to the following basic principles (IEA, 1999):

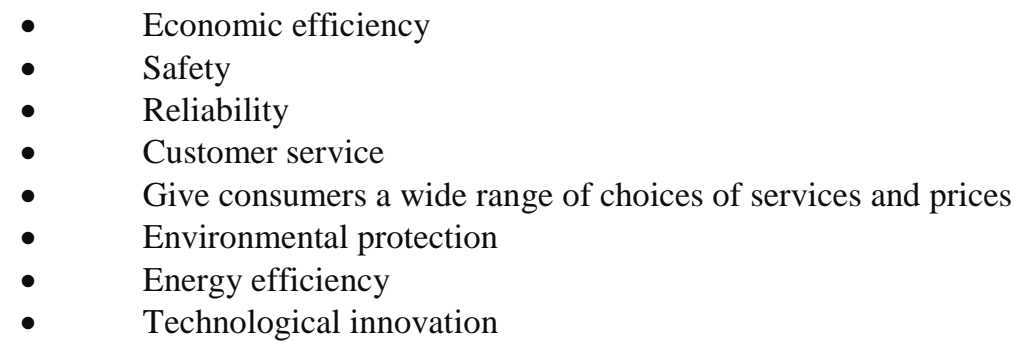

The Spanish Electricity Industry Association suggested additional considerations for a successful transition (UNESA, 1996):

- $\quad$ The length of the transition period should be adequate, to avoid disruptions.

- $\quad$ Develop guidelines for dealing with sunk costs, i.e. fixed capital investments already undertaken (who will pay for them? How much? When?)

- $\quad$ Assess whether consumers will contribute towards the costs of transition with a tax or surcharge.

- $\quad$ Establish independent entities responsible for the regulation and control of the process.

- Involve civil society in the decision-making over planning, location, environmental impact, and other sensitive issues.

- $\quad$ Be ready to reintroduce regulation over competition when the public interest requires it.

- $\quad$ No discrimination among operators for access to the transport and distribution networks.

- $\quad$ Existing contracts should be respected

\section{STAGES IN THE TRANSITION TO A DEREGULATED SYSTEM}

The specific characteristics of the transition process in a particular country depend on that country's starting position. However, in most cases the process involves the following five stages (CIGRE, 1999):

\section{A. Operational Separation of Vertically Integrated Activities \\ B. Complete Separation of Vertically Integrated Activities}


It is recommended (Perez Arriaga, 1998) that the same company should not undertake regulated activities (transmission and distribution) at the same time as competitive activities (generation and retailing). Depending on the circumstances, various degrees of separation ought to be considered:

- $\quad$ Accounting separation

- $\quad$ Management separation

- $\quad$ Legal separation within same conglomerate

- $\quad$ Complete legal separation

\section{Undoing of Horizontal Integration}

In order to establish a well functioning competitive market in electricity generation and retailing it is essential to have a certain minimum number of firms operating with a certain cap on the maximum market share allowed by any one firm.

\section{Creation of a Competitive Market}

In addition to having many firms operating in the market, without a high concentration ratio, it is important to have independent regulatory bodies that will ensure the maintenance of a competitive market.

\section{E. Privatization}

This stage is needed only in those cases where there is public ownership of companies and assets. It is very important to have in place an independent agency that will carry out the privatization process in a fair and transparent way.

\section{THE CONSTRUCTION OF THE INTERNAL MARKET FOR ENERGY IN THE EUROPEAN UNION}

With the adoption of the White Book and the Single European Act in 1985, the establishment of a Single European Market became one of the key goals of the European Union. The Single Market was defined as an area without internal borders which guarantees the free movement of goods, people, services and capital, aiming to promote competitiveness and thus the well-being of EU citizens. Within this general framework the European Union declared in 1986 that it seeks a better integration of its internal energy market, free of trade barriers, aiming at ensuring a reliable supply, lower costs and contributing to higher economic competitiveness.

The end result of this process of deliberations and negotiations aimed at deregulating electricity and natural gas markets was the adoption in December 1996 of Directive 96/92/CE establishing guidelines for an Internal Electricity Market, followed by Directive 98/30/CE establishing comparable guidelines for natural gas.

Member states were given a deadline of February 1999 for the implementation of the new guidelines.

The Directives gave the member states a substantial degree of flexibility regarding the specific process to be undertaken in order to achieve the stated goals. However, by late 2002 the European Commission determined that progress towards a true Internal Market in energy was insufficient. In July 2003 two new Directives were adopted (2003/54/CE and 2003/55/CE), deepening the liberalization process and setting a deadline of July 2007 for the complete liberalization of electricity and natural gas markets.

The actual progress experienced by different countries, however, has been quite uneven. The main emerging trends can be summarized as follows:

A. Britain has been the country that has created the most competitive environment, with a complete horizontal and vertical separation. A tough regulatory agency enforced a cap on firm size and market share. 
B. In Scandinavia, there has been a quite successful integration of the electricity systems of Norway, Sweden, Finland and Denmark. There has been a marked increase in competition, a greater diversification of energy sources, and a substantial decline in price differentials across countries.

C. One important common characteristic of Britain and Scandinavia is that in both cases electricity prices are set by bilateral contracts between buyers and sellers, which reduce risk and volatility.

D. The broad degree of leeway built into the EU Directives enabled the emergence of a hotchpotch of regulatory regimes in different member countries, with conflicting regulatory philosophies and various degrees of true market competition.

E. In a number of countries there has been an increase in ownership concentration and a decrease in competition.

F. There has been a very low volume of electricity exchanges among countries. This is due to a very underdeveloped infrastructure for interconnectivity. The interconnectivity blueprints were designed above all for security reasons and not for enabling free trade in electricity by deregulated companies.

G. Governments pledge to support and encourage liberalization but find it hard to give up their interventionist powers especially when it comes to setting energy prices, in a macroeconomic environment which assigns the highest priority to price stability.

H. There has not been sufficient emphasis on educating consumers and businesses on waste reduction and efficient energy use in order to slow down the rapid growth in demand.

In March 2006, the European Commission opened the debate on a future common European Energy Policy by publishing the Green Book "A European Strategy for Sustainable, Competitive and Secure Energy" (Commission of the European Communities, 2006). The Green Book identified six priority areas:

A. Take the necessary steps for completing the internal energy market for gas and electricity.

B. Ensure solidarity among EU member states in case of supply disruptions, with the creation of gas stocks along with the existing compulsory oil stocks. A European Energy Observatory would monitor market developments to enhance transparency of demand and supply.

C. Establish a more diversified, sustainable and efficient energy mix.

D. Address the serious issue of global warming by adopting a new road map for renewable energy and an Energy Efficiency Action Plan.

E. Implement a strategic energy technology plan to prevent overlaps in national technology and research programs and ensure EU industries lead the multi-billion market for new energy technologies.

F. Adopt a common external energy policy to co-ordinate relations with external suppliers such as Russia and OPEC countries. The policy would include a list of new pipelines and liquefied natural gas terminals to improve security of supply.

On December 17, 2008, the European Parliament approved a new legislative package on energy and climate change aimed at enabling the EU to reach the goals set for 2020, transforming Europe into a low-carbon economy and increasing energy security (Harvey and Chaffin, 2008). The specific goals approved were:

A. a 20\% reduction in greenhouse gas emissions;

B. a $20 \%$ improvement in energy efficiency; and

C. a $20 \%$ share for renewables in the EU's energy mix

Commenting on the legislative approval, the European Commission said that the EU was the first region in the world to commit to such far-reaching and legally-binding emission reductions, that the EU was leading the fight against climate change, and that the deal was an important contribution towards an ambitious international climate agreement expected to be reached at the Copenhagen Climate Conference in December 2009.

\section{CONCLUSIONS}

The process of liberalization of the electricity sector in Europe has been quite successful in some countries and a mixed bag in others, leaving a significant number of open questions regarding the way forward for such a critical sector. 
It is clear that a liberalized environment requires an industry made up of strong companies operating in a competitive market that have the means to prosper and grow, creating value for the shareholders and capable of coping with unexpected challenges. The problem is, however, that small and mid-sized companies are finding it harder and harder to survive when competing with larger European competitors with a strong national and international presence. This process is leading to a significant decline in the number of operators raising alarms about the survival of a competitive market in the long term.

Furthermore, there is a lack of clarity regarding the emerging market structure and the proper role of the regulatory agencies. If governments are not capable of maintaining a proper balance between economic, political and legislative considerations, the outcome may well be an inefficient system, plagued with high costs, poor quality and an unreliable supply.

Moreover, greater attention should be paid to the economic and social issues related to achieving a sustainable development, focusing on the dramatic consequences of climate change and the protection of the environment.

In summary, there is a great deal of interdependence between the chosen economic model, the market structure of the energy sector, the regulatory policies, the physical environment and the wellbeing of the population. These issues should be openly discussed and debated in each European country and in the supranational institutions given that there is so much at stake.

\section{AUTHOR INFORMATION}

Pere Palacín is a Professor of Electrical Technology in the Department of Industrial Engineering of the Institut Químic de Sarrià, and in the Department of Electrical Engineering of the Universidad Politécnica de Cataluña. He obtained a Ph.D. in Business Administration at the Ramon Llull University in Barcelona, and is currently active in research and consulting for numerous private and public organizations. He has had extensive corporate experience in the electricity sector at ENHER and at Red Eléctrica de España and played an active role in the implementation of the liberalized electricity market since 1998.

Carlos Moslares is a Professor of Economics and Finance, Chairman of the Economics Department, and Associate Dean at the IQS Business School of the Ramon Llull University in Barcelona. He holds a Ph.D. in Economics from Florida International University and has been a Visiting Professor at universities in the U.S., Mexico and Argentina. He has ample corporate and consulting experience in Spain, the U.S. and Algeria and is a member of the Executive Committee of the International Association of Applied Economics.

Hugo Hervitz teaches Managerial Economics in the MBA program at Nova Southeastern University in Ft. Lauderdale and is the director of the Forum-Nexus programs at the IQS Business School in Barcelona and the Universita Cattolica del Sacro Cuore in Milan. He has been a Professor of Economics in South Florida for over 25 years, specializing in International Trade and Deregulation in Europe and Latin America. Dr. Hervitz was born in Argentina and holds a Ph.D. in Economics from Indiana University and Master's degrees from the University of London and the University of Pittsburgh.

\section{REFERENCES}

1. Averch H. and L. Johnson (1962) "Behavior of the firm under regulatory constraint", American Economic Review, vol. 52, Dec., pp. 1052-1069.

2. CIGRE (1999) "Understanding the Electricity Industry Restructuring and Liberalisation Process", International Council on Large Electric Systems.

3. Commission of the European Communities (2006), "Green Paper: A European Strategy for Sustainable, Competitive and Secure Energy", Brussels, March 8.

4. European Commission (2005), "Annual Report of the Implementation of the Gas and Electricity Internal Market", Brussels 
5. Harvey, F. and Chaffin, J. (2008), "EU Climate Bill Ushers in Hard Year of Talks", Financial Times, December 18

6. IEA (1999), "Electricity Market Reform: An IEA Handbook", International Energy Agency

7. Perez Arriaga, J.I. (1998) "Fundamentos teóricos de la nueva regulación eléctrica", Madrid, CNSE.

8. UNESA (1996), "Reestructuración del sector eléctrico en California", Informe Internacional \#52, Spanish Association of Electricity Companies, Madrid

\section{NOTES}

